\title{
Chromatographic Analyses of Anti diabetic plants: Sclerocarya birrea (A. Rich) Hochst, Balanites aegyptiaca (L) Del, Ceiba pentandra (L) Gaertin.
}

\author{
Ousmane Kéita $^{1 *}$, Balla Dianka ${ }^{2}$, Sidi Sidiki Coulibaly ${ }^{3}$ \\ ${ }^{1,3}$ Food Biochemistry laboratory. Institute of the Sciences Applied of the University of the Sciences, the \\ Techniques and the Technologies of Bamako (USTTB) - Mali, P B : 423 Bamako, Mali \\ ${ }^{2}$ Laboratory of networks and telecommunication. Institute of the Sciences Applied of the university of the \\ Sciences, the Techniques and the Technologies of Bamako (USTTB) - Mali, P B: 423 Bamako, Mali
}

*Corresponding Author: Ousmane Kéita, Food Biochemistry laboratory. Institute of the Sciences Applied of the University of the Sciences, the Techniques and the Technologies of Bamako (USTTB) - Mali P B : 423 Bamako, Mali.

\begin{abstract}
Background: Diabetes, by its frequency and the cost of its treatment, is a barrier to development efforts. Thus, many patients base their hopes on anti-diabetic plants, which nevertheless require scientific proof. These plants may have several compounds such as alkaloids with anti-diabetic properties.
\end{abstract}

Objective: The aim of this study is the chromatographic analysis of Sclerocarya birrea (A. Rich) Hochst, Balanites aegyptiaca $(L)$ Del, Ceiba pentadra $(L)$ Gaertin in the treatment of diabetes.

Methods: The alkaloids were extracted with dichloromethane. These extracts were concentrated and purified through a column. After deposition and migration of extracts and standards, the plates were dried and the RF were calculated and compared. The extracts and increasing concentrations of the prepared standards have been injected into the HPLC device and their detection results in a peak with its retention time and surface. These alkaloids are identified by comparing the retention times of the standards and extracts.

Conclusion: The CCM analysis showed the presence of capsaicin, diphenylamine and lepidine in the different plant organs. The HPLC analysis gave for Ceiba pentandra roots with a content of $255.12 \mathrm{mg} / \mathrm{kg}$ lepidine, Sclerocarya birrea trunk bark with a concentration of $977.74 \mathrm{mg} / \mathrm{kg}$ and Balanites aegyptica leaves with a content of $23.82 \mathrm{mg} / \mathrm{kg}$.

These plants have an anti-diabetic activity that requires pharmacological tests.

Keywords: Antidiabetic plants, Chromatographic methods, Standards

\section{INTRODUCTION}

Diabetes, usually caused by too high blood sugar levels, was considered a disease of rich countries. The WHO estimates that this disease will be one of the most important by its magnitude in the next twenty years, mainly in developing countries. However, the socio-economic context and the traditional, high-carbohydrate diet, consisting of cereals or tubers with sauce, adds to the Western model of diet. Indeed, the frequency of this condition in two clinical components, insulin-dependent and non-insulin-dependent diabetes has doubled in the last fifteen years and is expected to double again in the coming decade. In the case of France, the number of diabetics is 2 million, $90 \%$ of whom have type 2 diabetes [1]. Diabetes mellitus is the main cause of polyneuropathy in the Western world, one of the most frequent complications [2]. Long considered as a disease of rich countries, diabetes has become a public health problem in Africa within a few years. The incidence of diabetes is estimated to be between 1 and 6\% of the sub-Saharan population, 3\% in Europe and 6 to 10\% in South Africa; it is estimated that there are about 5 million diabetics on the continent. In Mali, in Bamako, diabetes is a public health problem according to doctors; it is the second leading cause of hospitalization after HIV, and accounts for more than $95 \%$ of internal medicine consultations. The prevalence, i.e. the number of people affected out of the number of people exposed, is estimated at around $2 \%$ [3]. This new, more energetic form of diet, combined with a sedentary lifestyle and high 
urbanization, increases obesity and overweight [3]. The limited financial resources of the majority of patients make it inevitable to resort to the less expensive traditional pharmacopoeia in the short and long term. However, the promotion of this medicine and its integration into the health system of developing countries requires scientific proof of these therapeutic attributes. Today, the general situation of health coverage in our countries challenges us differently and, provided we have some capacity to reverse the degradation process, we will be more accountable for not reacting. The choice of medicinal plants is justified by the seriousness of the danger to human health posed by pathogens that recognize neither political borders nor natural and conventional barriers and which, in their evolution, cause enormous human losses and the economic impoverishment of African populations.

\section{Materials AND Methods}

\subsection{Plant Material and Preparation of the Extract}

The different organs of Sclerocarya birrea, Balanites aegyptiaca and Ceiba pentandra were harvested in 2014 in the botanical garden of the Cheikh Anta Diop University of Dakar and dried in the shelter of the sun at room temperature. $10 \mathrm{~g}$ of each ground organ was macerated with $100 \mathrm{~mL}$ of dichloromethane for 1 hour. After filtration, the extracts were dry evaporated at $70^{\circ} \mathrm{C}$ and recovered with $2 \mathrm{~mL}$ of $90^{\circ}$ ethanol.

\subsection{Purification of Extracts}

The chromatographic column was filled with $7 \mathrm{~g}$ of silica and $2 \mathrm{~g}$ of Na2SO 4 for the substances to be separated from all our samples. The solution of each sample is deposited at the top of the column. 100 $\mathrm{mL}$ of the dichloromethane fraction is collected and analyzed by thin-layer chromatography and dry evaporation at $70^{\circ} \mathrm{C}$ [4].

\subsection{Thin-Layer Chromatographic Analysis}

$1 \mu \mathrm{l}$ of capsaicin, diphenylamin, lepidin and of each extract to be analyzed are deposited on the chromatographic plate by means of the micro seringue on the base line located at $2 \mathrm{~cm}$ at the lower edge of the plate of dimension $20 \times 20 \mathrm{~cm}$ and placed in a chromatographic tank containing benzene : ethyl acetate : methanol (75:20:5 v/v). After migration, the plate is removed from the chromatographic tank, dried and then revealed with the alkaloid-specific Draggendorf reagent.

\subsection{Analysis of Extracts by High Performance Liquid Chromatography}

Increasing concentration ranges of capsaicin, diphenylamin, lepidin were prepared and injected successively into the device. Their detection results in the application of a peak (characteristic of each solution) whose retention time and surface area are then recorded.

The standard calibration line is obtained by plotting $S=f(C)$ where $S$ represents the peak area and $C$ the concentration of the standard solutions.

These alkaloids are identified by comparing the retention times of the standards and the sample extracts. The different concentrations of capsaicin, diphenylamin and lepidin contained in the extracts are determined from their calibration line knowing the surfaces.

\section{RESUlTS AND DISCUSSION}

\subsection{Thin Layer Chromatography}

The chromatograms of capsaicin and extracts are shown in figure 1.

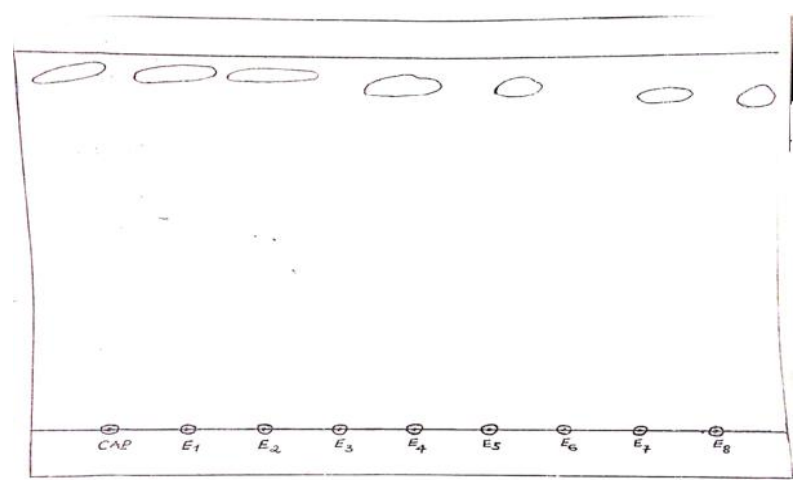

Figure1. Chromatograms of capsaicin and extracts Eluent; Benzene: Ethyl acetate: Methanol (75:20:5 v/v/v) CAP: Capsaicin (standard) 

aegyptiaca (L) Del, Ceiba pentandra (L) Gaertin.

E1: Root extract from Sclerocarya birrea, E2: Fruit extract from Balanites aegyptiaca

E3: Extract of leaves of Ceiba pentandra, E4: Extract of flowers of Balanite saegyptiaca

E5: Extract of fruits of Ceiba pentandra, E6: Extract of leaves of Balanites aegyptiaca

E7: Extract of bark from Ceiba pentandra,E8: Extract of leaves from Sclerocarya birrea All extracts would contain capsaicin with a relative error of $\pm 0,01$ to $\pm 0,02$.

\subsection{High Performance Liquid Chromatography}

Figure 2 shows the calibration line for diphenylamine. Its retention time is 1.31 . The calibration lines show correlation coefficients R (0.99499) close to unity, showing the reliability and accuracy of the method.

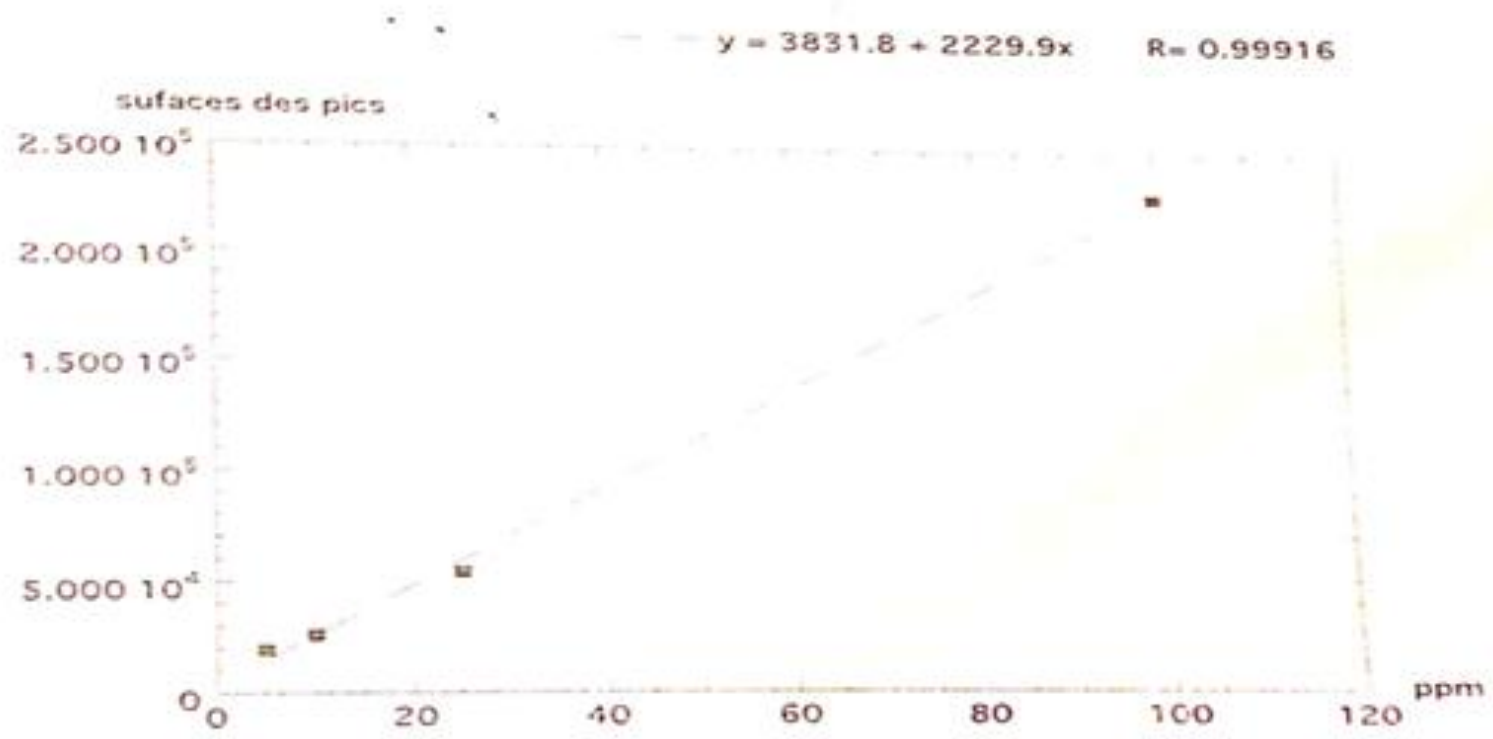

Figure2. Calibration line for Diphenylamine in ethanol (285 $\mathrm{nm}$ )

Figure 3 shows the chromatograms of lepidin and sample extracts.

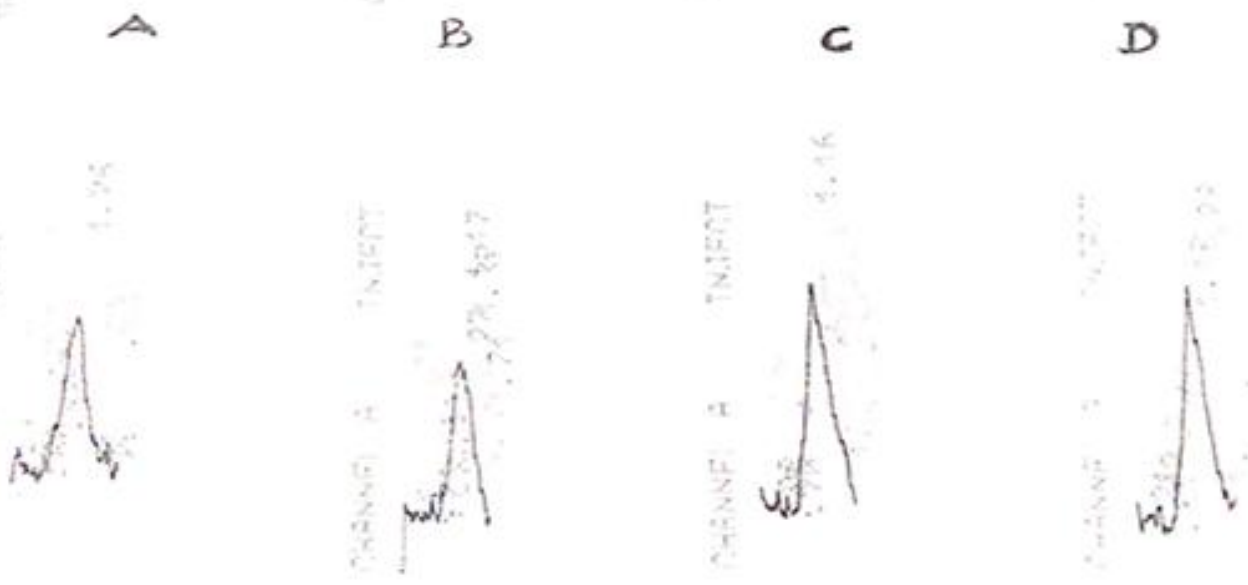

Figure3. Chromatograms of lepidin and 3 extracts analysed

A- Lepidin chromatogram (Standard)

B- Chromatogram of extract of bark from Balanite saegyptiaca bark

C- Chromatogram of Sclerocarya birrea bark extract

D- Chromatogram of Ceiba pentandra bark extract

The active ingredient content of the organs is shown in table II. 
Chromatographi cAnalyses of Antidiabetic plants: Sclerocarya birrea(A. Rich) Hochst, Balanites aegyptiaca (L) Del, Ceiba pentandra (L) Gaertin

TableII. Concentration of active ingredients in the different parts of the plants studied

\begin{tabular}{|c|c|c|c|c|}
\hline \multirow{2}{*}{ Plants } & \multirow{3}{*}{ Parts of plants } & \multicolumn{3}{|c|}{ Concentration in ppm of mg/kg } \\
\cline { 2 - 5 } & & Lépidin & Capsaïcin & Diphénylamin \\
\cline { 2 - 5 } & Roots & 255,12 & 15,39 & 0,54 \\
\cline { 2 - 5 } Ceiba pentandra & Fruits & 9,66 & 8,435 & 14,37 \\
\cline { 2 - 5 } & Flowers & ND & 14,30 & 10,03 \\
\cline { 2 - 5 } & Barks & 39,24 & 2,79 & 1,53 \\
\cline { 2 - 5 } & Leaves & ND & 114,75 & 102,64 \\
\hline \multirow{3}{*}{$\begin{array}{c}\text { Sclerocarya } \\
\text { birrea }\end{array}$} & Barks & 15,80 & 977,74 & 37,83 \\
\cline { 2 - 5 } & Roots & ND & 65,55 & 2,5 \\
\cline { 2 - 5 } Balanites \\
\cline { 2 - 5 } aegyptiaca & Leaves & ND & 21,43 & 0,48 \\
\cline { 2 - 5 } & Barks & 18,96 & 28,06 & 13,45 \\
\cline { 2 - 5 } & Roots & 17,28 & 24,06 & 23,82 \\
\cline { 2 - 5 } & Flowers & ND & 119,41 & 8,60 \\
\hline
\end{tabular}

ND: Not detected

Capsaicin was detected in all 13 samples tested with concentrations ranging from 1.38 to 977.74 $\mathrm{mg} / \mathrm{kg}$. Diphenylamin was detected in all 13 samples tested at concentrations ranging from 0.54 to $102.64 \mathrm{mg} / \mathrm{kg}$. 7 samples had lepidin concentrations ranging from 9.66 to $255.12 \mathrm{mg} / \mathrm{kg}$ and 6 samples did not.

Ceiba pentandra bark contains capsaicin, diphenylamine and lepidin $(40 \mathrm{mg} / \mathrm{kg})$. This may explain the hypoglycemic properties that occur as a result of hyperglycemia. These results are consistent with those of Dzeufiet et al who showed that a single dose of $40 \mathrm{mg} / \mathrm{kg}$ of chloroform/methanol extract from bark significantly reduced the blood glucose concentration in normal and diabetic rats by $40.0 \%$ and $48.9 \%$, respectively, after 8 hours [5]. Studies by Olusola et al. showed that the aqueous extract of the trunk bark of Ceiba pentandra has a hypoglycemic action with higher doses [6].

Roots and leaves of Sclerocarya birrea contain diphenylamin and capsaicin at concentrations below $70 \mathrm{mg} / \mathrm{kg}$. Their presence would explain the antidiabetic effect. Gueye showed that a decoction or maceration of leaves causes a decrease in blood glucose levels in rats when administered orally or intraperitoneally [7]. This work confirms our results. The bark contains capsaicin, lepidin and diphenylamin. The presence of these molecules could explain the hypoglycemic activity of the extract. Some authors have shown that the decoction of Sclerocarya birrea bark has a low toxicity [8].

This same decoction administered orally at a dose of $0.5 \mathrm{gr} / \mathrm{kg}$ lowers the blood sugar level of normoglycemic rats: the effect is significant two hours after treatment and the maximum decrease is observed after three hours.Leaves and bark contain lepidin, diphenylamin and capsaicin at concentrations below $30 \mathrm{mg} / \mathrm{kg}$. This may explain the hypoglycemic properties following hyperglycemia. These results are contrary to other work. In vitro studies revealed that the aqueous extract of the bark of Balanites aegyptiaca has an inhibitory activity of $\alpha$-amylase between $45-75 \%$ at $200 \mathrm{mg} / \mathrm{mL}$ and was able to inhibit the activity of intestinal alpha-amylase in a dose-dependent manner [9]. In 2018, studies reported that the bioactive substances present in the ethanolic extract of Balanites aegyptiaca showed the activity of alpha-amylase inhibition in vitro [10]. Balanites aegyptiaca succeeds in inducing hypoglycemia in diabetic rats but not in normoglycemic rats which is a desirable trait as hyperglycemia, has been found to cause a cascade of adverse effects [11].

\section{CONCLUSiON}

This study showed that certain extracts of Sclerocary abirrea, Balanites aegyptiaca and Ceiba pentadra contain capsaicin, diphenylamin and lepidin. This study requires the isolation of these active ingredients and extensive pharmacological studies for the management of diabetes 
Chromatographi cAnalyses of Antidiabetic plants: Sclerocarya birrea(A. Rich) Hochst, Balanites aegyptiaca (L) Del, Ceiba pentandra (L) Gaertin.

\section{REFERENCES}

[1] Chritelle, D. ; Hélène, T. Diabétologie -Nutrition et facteurs de risques, 2001.

[1] Ruiz, V. ; Ybarra, J. ; Desmeules, J. ; Piguet, V. ; Allaz, A. F. ; Dayer, P. Une douleur difficile : la neuropathie diabétique [Med.Hyg...], vol.54, n²114, 1996.

[2] Besancon, S. ; Grevost, J. Action/société Le diabète menace l'Afrique .appui au développement, santé, diabète, Mali, 2003.

[3] Ulrich, H. Maier, H. Seven imidazole alcaloids from lepidiumSativum Phytochemistry, vol.49 nº, 1998 , Pp : 1791-1795

[4] Dzeufiet, D.P.D. ; Tedong, L. ; Asongalem. E.A. ; Dimo, T. ; Sokeng, S.D. ; Kamtchouing, P. Hypoglycémie et effet antidiabétique d'extraits de racines de Ceibapentendra chez le rat normal et diabétique. African Journal of Traditional, Complementary and Alternative Medicines 3 (1) : 2006. Pp 129 $-136$

[5] Olusola, L. ; Ike, C.O. ; Mariam, S. Les propriétés hypoglycémiques de l'extrait aqueux d'écorce de Ceibapentandra chez les rats diabétiques induits par la streptozotocine. J Ethnopharmacol 2003; 84:13942.

[6] Travato, A. ; Kirjavainen, S. ; Galatie, M. ; Forestie, A.M. Effect of SclerocaryabirreaHochst Extract on Some metabolie activities in the rat.Photo therapy research, 9, (8), 1995, pp : 591-593

[7] Funke, I ; Melzing, M.F. ; Les plantes traditionnellement utilisées dans la thérapie du diabète - la phytothérapie - comme inhibiteurs de l'activité $\alpha$-amylase. Rev Bras Farmacogn. 2006 (1) ; 16 : 1-5.

[8] Gad, M.Z. ; El-Sawalhi, M.M., Ismail, M.F. ; El- Tanbouly, N.D. Étude biochimique de l'action antidiabétique des plantes égyptiennes Fenugrec et Balanites. Mol Cell Biochem 2006 ; 281 (1-2) : 173-83.

[9] Gawade, B. ; Farooqui, M. Investigation de l'activité phytochimique et d'inhibition de l'alpha amylase des feuilles de Balanites aegyptiaca. Res J PharmBiolChemSci. 2018 ; 9 (1) : 459-64.

[10] Snell-Bergeon, J.K. ; Wadwa, R.P. Hypoglycémie, diabète et maladies cardiovasculaires. Diabetes TechnolTher $2012 ; 14$ (1) : S51-S58

Citation: Ousmane Kéita, et.al, "Chromatographi cAnalyses of Antidiabetic plants: Sclerocarya birrea(A. Rich) Hochst, Balanites aegyptiaca (L) Del, Ceiba pentandra (L) Gaertin. ”, International Journal of Advanced Research in Chemical Science, vol. 7, no.1, p. 22-26, 2020. DOI: http://dx.doi.org/10.20431/23490403.0701004

Copyright: () 2020 Authors. This is an open-access article distributed under the terms of the Creative Commons Attribution License, which permits unrestricted use, distribution, and reproduction in any medium, provided the original author and source are credited. 